\title{
Studies on Cultural and Physiological Variability of Alternaria porri (Ellis) Cif. - A Causative of Purple Blotch of Onion (Allium cepa L.)
}

\author{
R.U. Priya ${ }^{1^{*}}$, Arun R. Sataraddi ${ }^{2}$ and T.R. Kavitha ${ }^{1}$ \\ ${ }^{1}$ University of Agricultural sciences, Bengaluru, Karnataka, India \\ ${ }^{2}$ KVK, Bagalkot, UAS, Dharwad - 580 005, Karnataka, India \\ *Corresponding author
}

\section{A B S T R A C T}

K e y w o r d s
$\begin{aligned} & \text { Alternaria porri, Purple } \\ & \text { blotch disease, Onion, } \\ & \text { Cultural and } \\ & \text { morphological variability }\end{aligned}$
Article Info
$\begin{aligned} & \text { Accepted: } \\ & \text { 17 July } 2018 \\ & \text { Available Online: } \\ & \text { 10 August } 2018\end{aligned}$

\section{Introduction}

Onion (Allium cepa L.) (Latin 'cepa' = onion), known as the bulb onion or common onion and is commonly called as "Queen of Kitchen" Onion is a vegetable crop of global importance and is known as protective food. It also owns potent medicinal value in ayurvedic and homeopathic therapy.

Being a rich source of minerals, vitamins, dietary fibers and is also regarded as anticancer foodstuff (Griffiths, 2002). Onion is an important spices crop commercially grown in many countries of the world. Out of 15 important vegetables and spice crops listed by FAO, onion stands second in terms of annual world production (Ali, 2008). In the world, India ranks first in total area and ranks second after China. In India, onion occupies an area of 1.20 million hectare area, with a production of 19.40 million tonnes and a productivity of 16.10 metric tonnes/ha in the year 2013-2014 (Anon., 2015).

Several factors have been identified for the low productivity of onion in India. The most important factors responsible are the diseases like purple blotch, downy mildew, stemphylium blight, basal rot and storage rots etc. Among the foliar diseases, purple blotch is one of the most destructive diseases, 
commonly prevailing in almost all onion growing pockets of the world, Irrespective of the varieties, the spectrum of diseases that affect onion remain the same which causes heavy loss in onions under field conditions (Chethana et al., 2018). Losses ranged from 50 to 100 per cent (Angell, 1929).

Variability studies are important to document the changes occurring in populations and individuals as variability in morphological and physiological traits indicate the existence of different pathotypes. Variability is a wellknown phenomenon in genus Alternaria and may be noticed as changes in spore shape and size, growth and sporulation, pathogenicity, etc. Though ample information on these aspects of Alternaria pathogen on other hosts is available in literature but little is known about these requirements of Alternaria porri on onion. Hence the present study was undertaken to identify and characterize $A$. porri isolates to find out their extend of variation in cultural and morphological aspects.

\section{Materials and Methods}

\section{Isolation of the pathogen from purple} blotch infected sample

The pathogen (Alternaria porri) from the purple blotch infected leaf samples collected from different areas of Northern Karnataka were isolated separately by following tissue isolation technique. The infected leaves along with healthy portions were cut into small bits and were surface sterilized with 1:1000 mercuric chloride solutions for 30 seconds and washed three times in sterile distilled water before transferring them to potato dextrose agar. The plates were incubated at room temperature $\left(28 \pm 1^{0} \mathrm{C}\right)$ and observed periodically for fungal growth. The colonies which developed from the tissue bits were transferred to PDA slants.

\section{Cultural and morphological variability of Alternaria porri}

The growth characters of Alternaria porri were studied on nine solid media viz., host extract agar $+2 \%$ sucrose, oat meal agar, potato dextrose agar, yeast extract agar, Tochinai's agar, Czapecks agar, Sabouraud's dextrose agar, carrot agar and Richards's agar.

Twenty milli litres of each of the sterilized medium was poured into each of sterilized Petri dishes and allowed to solidify. Inoculation was made by transferring the five milli meter disc of mycelial mat, taken from the periphery of 10 day old culture. Each treatment was replicated thrice. The plates were incubated at $28 \pm 1{ }^{0} \mathrm{C}$. Observations on colony radial growth was taken when the maximum growth was attained in any one of the media tested. Other cultural characters viz., rate of growth, colony colour and morphological characters like sporulation and conidial characters were also recorded.

\section{Results and Discussion}

The isolated cultures were purified by single spore isolation technique and they were designated as Ap1 (Managuli isolate), Ap2 (Telagi isolate), Ap3 (Hunagund isolate), Ap4 (Naragund isolate), Ap5 (Annigeri isolate) and Ap6 (Kalakeri isolate).

The cultural characteristics of $A$. porri isolated from onion was studied on nine solid media as described in material and methods and the results of the study are presented (Table 1). The study revealed that there was significant difference between the different media and isolates. Among the media tested Czapeck's agar supported maximum radial growth $(8.80$ $\mathrm{cm})$ and was significantly superior over all other media. Next best media were potato dextrose agar $(8.60 \mathrm{~cm})$ and host extract $+2 \%$ sucrose $(8.60 \mathrm{~cm})$ and were found to be on par 
with carrot agar $(8.50 \mathrm{~cm})$ followed by Richard's agar $(8.30 \mathrm{~cm})$, Sabouraud's agar $(8.30 \mathrm{~cm})$ and oat meal agar $(7.90 \mathrm{~cm})$ and that is on par with yeast extract agar media $(7.80 \mathrm{~cm})$. The least radial growth was obtained in Tochinai's agar $(4.50 \mathrm{~cm})$.

Among the isolates tested, Ap5 had recorded the maximum radial growth $(8.20 \mathrm{~cm})$ and was significantly superior over all other isolates. Next best isolate was Ap1 $(8.00 \mathrm{~cm})$ which was on par with Ap2 $(7.90 \mathrm{~cm})$ and Ap4 (7.90 $\mathrm{cm})$. Later two isolates were also on par with Ap3 $(7.80 \mathrm{~cm})$ and Ap6 $(7.80 \mathrm{~cm})$ isolates.

With respect to interaction of isolate $\mathrm{x}$ media combination, isolate Ap5 has recorded maximum radial growth on Czapeck's agar $(9.00 \mathrm{~cm})$ which was on par with Ap1 $(8.90$ $\mathrm{cm})$, Ap3, Ap4, Ap6 $(8.80 \mathrm{~cm})$ on the same media and Ap5 on host extract $+2 \%$ sucrose agar $(8.80 \mathrm{~cm})$ followed by Ap1, Ap4, Ap5 $(8.70 \mathrm{~cm})$ on potato dextrose agar and Ap4 on host extract $+2 \%$ sucrose agar $(8.70 \mathrm{~cm})$.
Least radial growth was observed in Ap3 on Tochinai's agar media $(3.90 \mathrm{~cm})$.

Madhavi et al., (2012) has been made an attempt to identify and study the growth pattern of Alternaria porri that causes purple blotch of onions and proved Czapeck-Dox medium was best to support the growth of fungus. Similar observations were obtained by Ramjegathesh and Ebenezar (2012) that, among the solid media tested, host leaf extract agar and modified Czapek's dox medium increased the growth of mycelium followed by potato dextrose agar medium and carrot agar medium.

It was further observed that the colony characters, growth and sporulation of A. porri of six isolates on Czapeck's agar media (Table 2 and Plate 1). Ap1 isolate exhibited colony characters as brownish black coloured, flat mycelial growth with smooth margin merged topography of mycelium with poor sporulation.

Table.1 Variability of growth of isolates of Alternaria porri on different solid media

\begin{tabular}{|c|c|c|c|c|c|c|c|c|}
\hline \multirow[t]{2}{*}{$\begin{array}{c}\text { Sl } \\
\text { No }\end{array}$} & \multirow[t]{2}{*}{ Media } & \multicolumn{6}{|c|}{$\begin{array}{l}\text { Radial growth of isolates of Alternaria porri } \\
\qquad(\mathrm{cm})\end{array}$} & \multirow[t]{2}{*}{ Mean } \\
\hline & & Ap1 & Ap2 & Ap3 & Ap4 & Ap5 & Ap6 & \\
\hline 1 & Richard's agar & 8.30 & 8.00 & 8.30 & 8.36 & 8.60 & 8.30 & 8.30 \\
\hline 2 & Czapeck's agar & 8.90 & 8.60 & 8.80 & 8.80 & 9.00 & 8.80 & 8.80 \\
\hline 3 & Tochinai's agar & 4.40 & 4.60 & 3.90 & 4.20 & 5.50 & 4.40 & 4.50 \\
\hline 4 & Sabouraud's agar & 8.50 & 8.10 & 8.40 & 8.30 & 8.50 & 8.20 & 8.30 \\
\hline 5 & Host-extract $+2 \%$ Sucrose & 8.50 & 8.50 & 8.60 & 8.70 & 8.80 & 8.50 & 8.60 \\
\hline 6 & Oat meal agar & 8.00 & 7.90 & 7.60 & 7.80 & 8.60 & 7.80 & 7.90 \\
\hline 7 & Potato dextrose agar & 8.70 & 8.40 & 8.60 & 8.70 & 8.70 & 8.50 & 8.60 \\
\hline 8 & Carrot agar & 8.50 & 8.60 & 8.60 & 8.60 & 8.70 & 8.40 & 8.50 \\
\hline 9 & Yeast extract agar & 8.00 & 8.20 & 7.80 & 7.60 & 7.70 & 7.70 & 7.80 \\
\hline & Mean & 8.00 & 7.90 & 7.80 & 7.90 & 8.20 & 7.80 & 7.90 \\
\hline \multicolumn{3}{|c|}{ Sources of variance } & \multicolumn{3}{|c|}{ S. Em \pm} & \multicolumn{3}{|c|}{ CD at $1 \%$} \\
\hline \multicolumn{3}{|c|}{ Isolates (I) } & \multicolumn{3}{|c|}{0.03} & \multicolumn{3}{|c|}{0.14} \\
\hline \multicolumn{3}{|c|}{ Media (M) } & \multicolumn{3}{|c|}{0.04} & \multicolumn{3}{|c|}{0.17} \\
\hline \multicolumn{3}{|c|}{$\mathbf{I} * \mathbf{M}$} & \multicolumn{3}{|c|}{0.11} & \multicolumn{3}{|c|}{0.42} \\
\hline
\end{tabular}


Table.2 Colony characters, growth and sporulation of A. porri isolates on Czapeck's agar media

\begin{tabular}{|c|c|c|c|c|}
\hline SI & Isolates & \multicolumn{3}{|c|}{ Colony characters } \\
\hline No & & Colour & Growth characters & Sporulation \\
\hline 1 & Ap1 & Brownish black & $\begin{array}{l}\text { Flat mycelial growth with smooth } \\
\text { Margin merged topography of mycelium }\end{array}$ & + \\
\hline 2 & Ap2 & Dark brown & $\begin{array}{l}\text { Medium fluffy growth with smooth } \\
\text { margin and submerged topography }\end{array}$ & + \\
\hline 3 & Ap3 & Brownish black & $\begin{array}{l}\text { Medium fluffy growth with smooth } \\
\text { margin and submerged topography }\end{array}$ & + \\
\hline 4 & Ap4 & Grayish black & $\begin{array}{l}\text { Slight raised growth with irregular } \\
\text { margin and merged topography }\end{array}$ & + \\
\hline 5 & Ap5 & Grayish black & $\begin{array}{l}\text { Good and raised growth with merged } \\
\text { topography }\end{array}$ & + \\
\hline 6 & Ap6 & Dark gray & $\begin{array}{l}\text { Slight raised growth with irregular } \\
\text { margin and submerged topography }\end{array}$ & + \\
\hline
\end{tabular}

-No sporulation (no spores/ microscopic field)

+ Moderate sporulation ( $>5-20$ spores/microscopic field)

++ Good sporulation (>20-25 spores/ microscopic field)

++++ Excellent sporulation ( $>25$ spores/ microscopic field)

Table.3 Conidial characters of $A$. porri of six isolates on Czapeck's agar media

\begin{tabular}{|c|c|c|c|c|c|}
\hline \multirow{2}{*}{$\begin{array}{l}\text { Sl. } \\
\text { No. }\end{array}$} & \multirow[t]{2}{*}{ Isolates } & \multicolumn{4}{|c|}{ Conidial characters } \\
\hline & & $\begin{array}{c}\text { Conidial size } \\
\qquad(\mu \mathrm{m})\end{array}$ & $\begin{array}{c}\text { Beak length } \\
(\mu \mathrm{m})\end{array}$ & $\begin{array}{l}\text { Horizontal } \\
\text { septa (Nos.) }\end{array}$ & $\begin{array}{c}\text { Vertical septa } \\
\text { (Nos.) }\end{array}$ \\
\hline 1 & Ap1 & $27.13 \times 5.6$ & 26.60 & $6-7$ & $1-2$ \\
\hline 2 & Ap2 & $32.21 \times 10.2$ & 28.12 & $7-8$ & $1-2$ \\
\hline 3 & Ap3 & $67.2 \times 14.5$ & 70.45 & $8-10$ & $1-3$ \\
\hline 4 & Ap4 & $88.6 \times 18.1$ & 86.12 & $8-10$ & $1-2$ \\
\hline 5 & Ap5 & $101.6 \times 17.2$ & 90.20 & $10-12$ & $1-3$ \\
\hline 6 & Ap6 & $74.2 \times 15.1$ & 79.12 & $8-9$ & $1-2$ \\
\hline
\end{tabular}


Plate.1 Growth of Alternaria porri isolates on different solid media

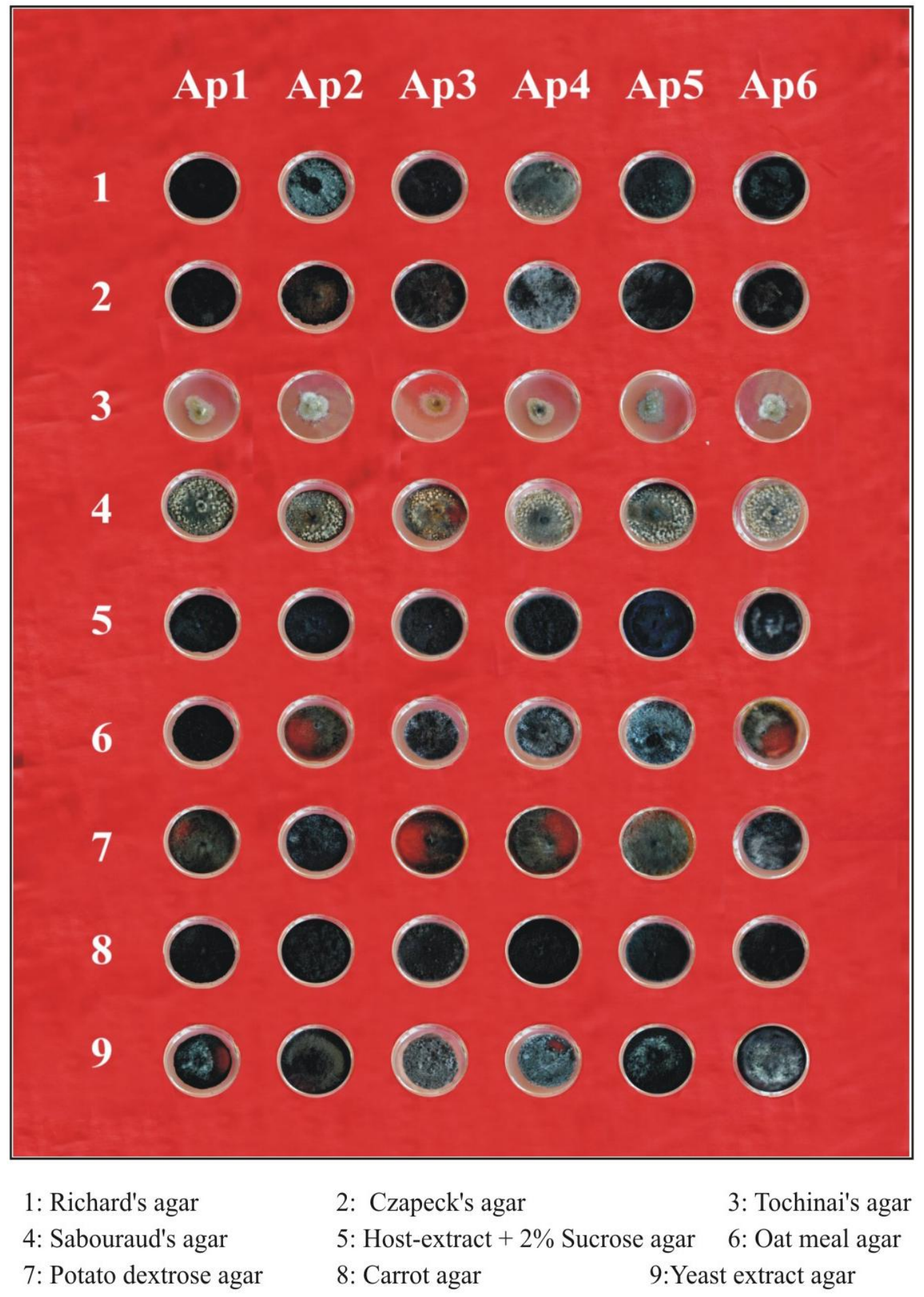


Plate.2 Conidia of Alternaria porri isolates

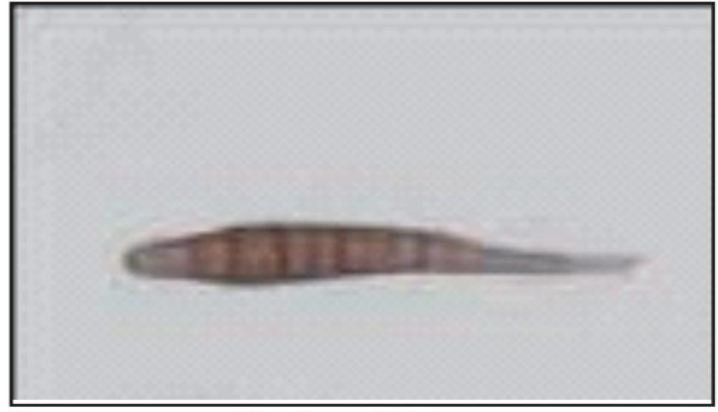

Isolate Ap 1

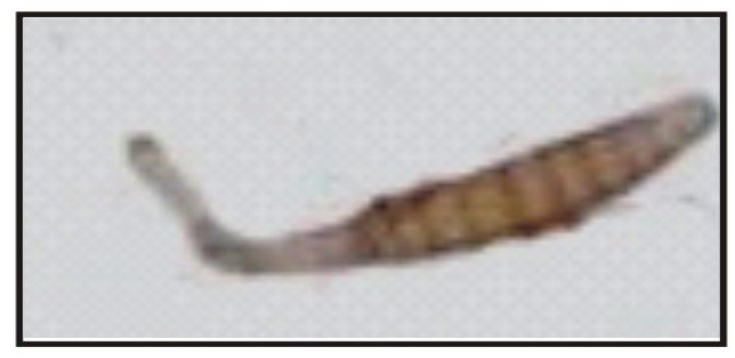

Isolate Ap3

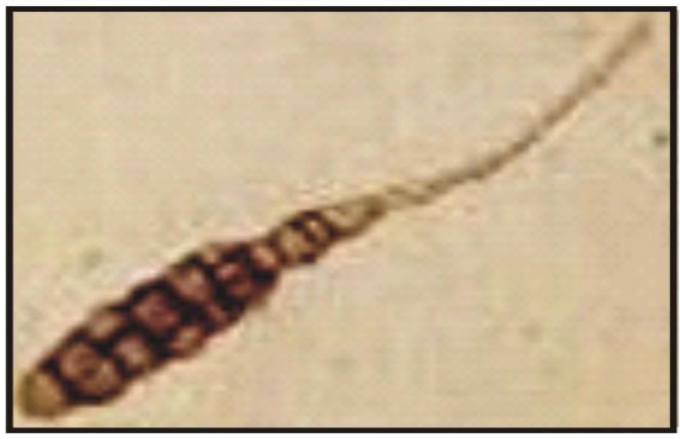

Isolate Ap5

While in Ap2 isolate dark brown coloured, medium fluffy growth with smooth margin and submerged topography of colony characters were found out with poor sporulation was recorded Ap3 isolate showed that the colony characters as brownish black coloured medium fluffy growth with smooth margin and submerged topography with

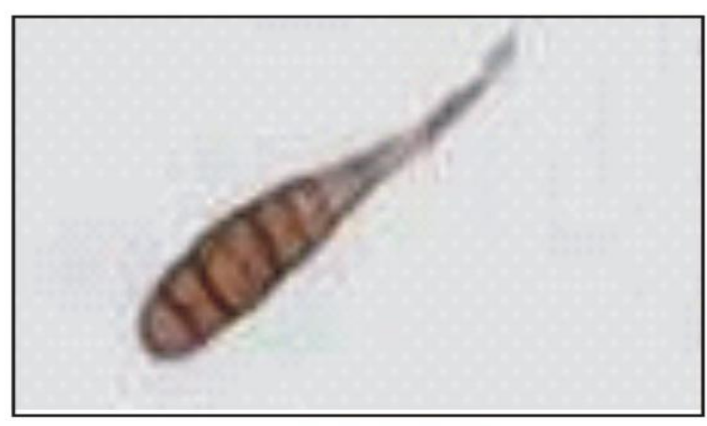

Isolate Ap2

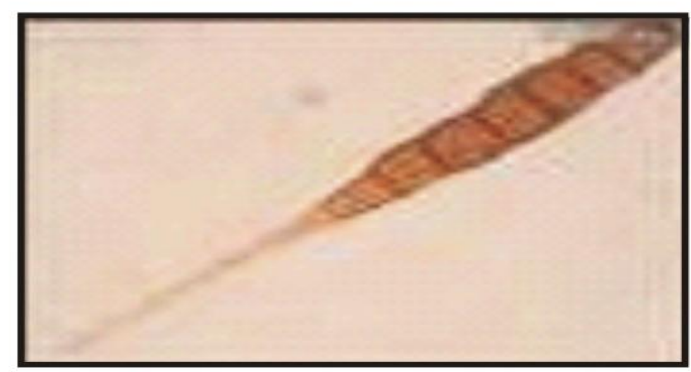

Isolate Ap4

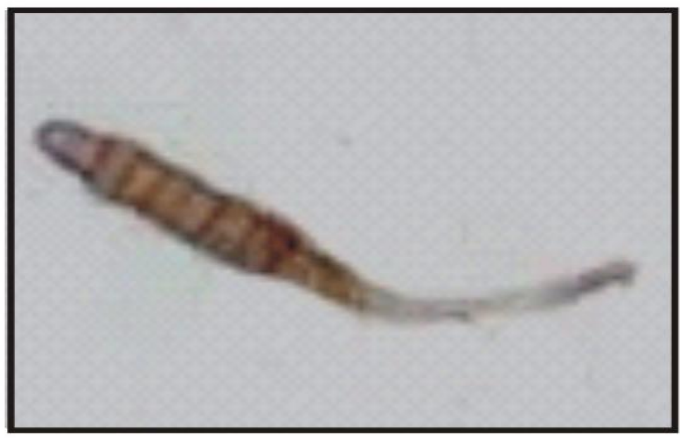

Isolate Ap6

moderate sporulation. Isolate Ap4 showed grayish black coloured slight raised growth with irregular margin and merged topography of colony characters with moderate sporulation whereas, in case of Ap5 isolate observations revealed that grayish black coloured good and raised growth with merged topography of colony and with moderate 
sporulation. While in Ap6 isolate colony characters like dark gray coloured slight raised growth with irregular margin and submerged topography with moderate sporulation was observed. Mohsin et al., (2016) reported that the isolates of A. porri showed variation in growth rate, colony colour, shape, margin, texture and substrate colour.

Present findings are in accordance with Pusz (2009) reported that colony colour varied from light to dark olivacious with greenish or brownish tinge and the colonies had velvety or cottony mycelial growth with slight variations and regular to irregular margin. Most of the isolates of $A$. porri depicted blackish green color on three tested media (Prakasam, 2010). Chowdappa et al., (2012) described that $A$. porri exhibited greyish orange or brownish orange in colony color with a cottony texture. Shahnaz et al., (2013) stated that the mycelial characteristics varied on different media from smooth to fluffy and whitish to dark olivaceous. Chethana et al., (2018) revealed that the isolates of $A$. porri showed significant variation in cultural characters viz., colony colour, growth pattern, margin and colony colour on the reverse side of the plate and the isolates were characterized by regular, irregular, circular, smooth and rough colonies.

On Czapeck's media, the conidial characters of six isolates of $A$. porri was detected (Table 3 and Plate 2). Isolate Ap1 exhibited conidial size of $27.13 \times 5.6 \mu \mathrm{m}$ with a beak length of $26.60 \mu \mathrm{m}$ and horizontal septa ranged from 6 7 with vertical septa of 1-2. Ap2 isolate revealed that conidial size of $32.21 \times 10.2 \mu \mathrm{m}$ with a beak length of $28.12 \mu \mathrm{m}$ and horizontal septa ranged from 7-8 with vertical septa of 12. While Ap3 showed the conidial size of 67.2 $\mathrm{x} 14.5 \mu \mathrm{m}$ with a beak length of $70.45 \mu \mathrm{m}$ and horizontal septa ranged from 8-10 with vertical septa of 1-3. Ap4 showed that conidial size of $88.6 \times 18.1 \mu \mathrm{m}$ with a beak length of $86.12 \mu \mathrm{m}$ and horizontal septa ranged from 8-10 with vertical septa of 1-2. Ap5 exhibited conidial size of $101.6 \times 17.2$ $\mu \mathrm{m}$ with a beak length of $90.20 \mu \mathrm{m}$ and horizontal septa ranged from 10-12 with vertical septa of 1-3. While in Ap6 isolate observed that conidial size of $74.2 \times 15.1 \mu \mathrm{m}$ with a beak length of $79.12 \mu \mathrm{m}$ and horizontal septa ranged from 8-9 with 1-2 vertical septa.

These results are in agreement with Utikar and Padule (1980) who reported light to dark brown conidia with uniform 1-6 transverse septa and 0-2 longitudinal septa, and variable in size and shape, mostly obclavate to oval with rudimentary beak and measured 10.2677.52 x 4.56-14.82 $\mu \mathrm{m}$ (Average $42.45 \mathrm{x}$ $10.27 \mu \mathrm{m})$.

Similarly Madhavi et al., (2012) reported that conidia of Alternaria porri were 100-300 $\mu \mathrm{m}$ long, 15 to $20 \mu \mathrm{m}$ thick, solitary, straight or curved with the body of conidium ellipsoidal tapering to the beak and having 7 to 9 transverse septa and 1 to 3 longitudinal septa. With the above characteristics, the pathogen was identified as Alternaria porri in accordance to the report of Ellis (1971).

Shahnaz et al., (2013) reported the differences among isolates in conidial length, width and number of septa in Alternaria porri and they obtained the maximum conidial length $(230.42 \mu \mathrm{m})$ was of isolate RE-6, followed by K-1 and G-7 $(196.70 \mu \mathrm{m})$ and the minimum conidial length (101.16) $\mu \mathrm{m}$ was recorded in C-10 and RS-5 isolates. Chethana et al., (2018) recorded the average conidial length of A. porri isolates ranged between 17.90 to $76.15 \mu \mathrm{m}$.

From the above studies it is confirmed that the fungus exhibited cultural as well as morphological variability and this may be due to some of the changes in their genetical 
constitution and influence of different environmental conditions from where they have been isolated. Hence it is crucial by knowing the nature of growth of pathogen whether it is vigorous or slow, the management practices may be applied.

\section{References}

Ali, M. H. 2008. Control of purple blotch complex of onion through fertilizer and fungicide application. M. Sc. Thesis, Department of Plant Pathology, Sher-eBangla Agricultural University.

Angell, H. R., 1929, Purple blotch of onion Macrosporium porri (Ellis) J. Agric. Res. 38: 467-487.

Anonymous. 2015. www.Nhb.gov.in.

Chethana, B. S., Ganeshan, G., Rao, A. S. and Bellishree, K. 2018. Morphological and Molecular characterization of Alternaria Isolates causing Purple blotch disease of Onion. Int.J.Curr.Microbiol.App.Sci. 7(4): 3478-3493.

Chowdappa, P., Sandhya and Bhargavi, B.R., 2012. Diversity analysis of Alternaria porri (Ellis) Cif - causal organism of purple leaf blotch of onion. Int. J. Innov. Horticul. 1(1): 11-17.

Ellis, M. P., 1971, Dematious Hyphomycetes, Common Wealth Mycological Institute, Kew Surrey, England. pp. 132-137.

Griffiths, G., Trueman, T., Crowther, T. and Thomas. B. 2002. Onion: A global benefit to health. Phytotheraphy Res. 17: 603-615.

Madhavi, M., Kavitha. A. and Vijayalakshmi, M., 2012, Studies on Alternaria porri (Ellis) Ciferri pathogenic to Onion (Allium cepa L.). Archives of Appl Sci Res. 4 (1): 1-9.

Mohsin, S. M., Islam, M. R., Ahmmed, A. N. F., Nisha, H. A. C. and Hasanuzzaman, M. 2016. Cultural, Morphological and Pathogenic Characterization of Alternaria porri Causing Purple Blotch of Onion. Not Bot Horti Agrobo, 44(1): 222-227.

Prakasam, 2010. Characterization and management of Alternaria porri incitant of purple blotch of onion. Ph D thesis. Indian Agricultural Research Institute, New Delhi. 182p.

Pusz, W., 2009, Morpho-physiological and molecular analyses of Alternaria alternata isolated from seeds of Amaranthus. Phytopathol. 54: 5-14.

Ramjegathesh, R. and Ebenezar, E. G., 2012, Morphological and physiological characters of Alternaria alternate causing leaf blight disease of Onion. Int. J. Pl. Pathol. 3(2): 34-44.

Shahnaz, E., Razdan, V. K., Andrabi, M and Rather, T. R. 2013. Variability among Alternaria porri isolates.Indian phytopath. 66 (2): 164-167.

Utikar, P. G. and Padule, D. N., 1980, A virulent species of Alternaria causing leaf blight of onion, Indian Phytopath. 33: 335-336.

\section{How to cite this article:}

Priya, R.U., Arun R. Sataraddi and Kavitha, T.R. 2018. Studies on Cultural and Physiological Variability of Alternaria porri (Ellis) Cif. - A Causative of Purple Blotch of Onion (Allium cepa L.). Int.J.Curr.Microbiol.App.Sci. 7(08): 3284-3291. doi: https://doi.org/10.20546/ijcmas.2018.708.350 